\title{
O MITO DA CAPITAL DAS NAÇÕES: \\ CURITIBA E A IMIGRAÇÃO - O CASO DOS ITALIANOS
}

\author{
THE MYTH OF A NATION'S CAPITAL: \\ CURITIBA AND IMMIGRATION - THE CASE OF THE ITALIANS
}

\section{EL MITO DE LA CAPITAL DE LAS NACIONES: CURITIBA Y LA INMIGRACIÓN - EL CASO DE LOS ITALIANOS}

\section{Rosana Zafalon}

Geógrafa, mestra e doutoranda do Programa de Pós-Graduação em Geografia da Universidade Federal do Paraná (UFPR).E-mail: rosanazafalon@gmail.com

\section{Resumo}

Nas últimas décadas, tem sido reproduzido, por meio do marketing político, um discurso de valorização étnica, na cidade de Curitiba (Paraná), retomando-se a antiga discussão sobre as características singulares que formam a identidade local, típica do paranismo do início do século XX. No entanto, atualmente, este discurso se materializa na forma de símbolos espalhados pela cidade, o que tende a solidificar essa imagem entre a população. Mas, ao contrário do que se possa pensar num primeiro momento, os grupos étnicos valorizados são apenas aqueles que se encaixam na imagem europeia de Curitiba (como, por exemplo, os italianos), o que torna os negros e os índios invisíveis neste espaço, embora tenham em muito contribuído para a formação desta sociedade. Por sua vez, o discurso identitário sobre a imigração italiana tem sido também aproveitado para fomentar o turismo rural, na Região Metropolitana de Curitiba.

Palavras-chave: imigração, identidade, italianos, turismo rural, Curitiba/PR.

\section{Abstract}

In the last decades, a discourse about ethnic appreciation in the city of Curitiba (Paraná state/Brazil) has been reproduced through political marketing, restarting an old discussion about the singular characteristics that form the local identity, typical of the "paranismo" (a movement in which politicians, artists and intellectuals worked together in order to build the identity of the population originating from the state of Paraná in the south region of Brazil) from the beginning of 20th century. However, this discourse currently materializes through symbols spread all around the city, which tends to set this image among the population. But contrary to what one might think at first, the only ethnic groups being valued are the ones that fit the image of the European heritage in Curitiba, such as the Italians. This makes black people and the indigenous population, who deeply contributed for the establishment of this society, invisible in this space. In turn, this identity discourse about the Italian immigration has been seized in order to foster the rural tourism in and around the city of Curitiba.

Keywords: immigration, identity, Italians, rural tourism, Curitiba (PR/Brazil). 


\section{Resumen}

En las últimas décadas, ha sido reproducido a través del marketing político, un discurso de valoración étnica en la ciudad de Curitiba (estado de Paraná, Brasil), retomando la antigua discusión sobre las características singulares que forman la identidad local ("paranismo"), típica de este estado en principios del siglo 20. Sin embargo, actualmente, ese discurso se materializa en forma de símbolos esparcidos por la ciudad, lo que tiende a solidificar esa imagen entre la población. Pero la diferencia de lo que se puede pensar de inmediato es que los grupos étnicos valorados son sólo aquellos que se encuadran en la imagen europea de Curitiba (como, por ejemplo, los italianos), lo que los hacen negros e indios invisibles en ese espacio, aunque tengan contribuido en gran medida para la formación de esa sociedad. Por su parte, el discurso identitário sobre la inmigración italiana ha sido también oportuno para fomentar el turismo rural en la Región Metropolitana de Curitiba.

Palabras claves: inmigración, la identidad, italianos, turismo rural, Curitiba (PR/Brasil). 


\section{Introdução}

Quando pensamos em uma identidade regional para o Sul do Brasil, logo se fala na questão racial: o Sul como o cenário europeu em território brasileiro; a região onde a escravidão não foi significativa; a terra dos "brancos". Nesse contexto, Curitiba, a capital do estado do Paraná, é descrita como "a cidade mais europeia” do Brasil.

De fato, esse imaginário tem sido construído pelo discurso histórico oficial, pelas políticas públicas e pelo marketing político, o que transformou a capital paranaense, aos olhos da população em geral, como a terra acolhedora de imigrantes. No entanto, quando examinamos cientificamente essa questão, a verdadeira identidade da relação entre Curitiba e os diversos povos que formaram sua população se revela bem diferente.

A construção da identidade europeia de Curitiba se relaciona diretamente à construção da própria identidade paranaense, sendo que ambas estão fundamentadas em noções raciais, em que os grupos sociais possuem "valores" diferenciados, os negros e índios são praticamente invisíveis, enquanto os brancos europeus são supervalorizados. Desse modo, podemos afirmar que a cidade de Curitiba incorpora os componentes migratórios que lhe são convenientes para a construção de sua identidade branca e invisibiliza os grupos que fogem deste padrão.

Portanto, o presente artigo se propõe a discutir a imigração no Paraná, com foco na cidade de Curitiba, a construção da identidade curitibana, a relação diferenciada que se estabelece com os grupos imigrantes e, de modo especial, o caso da imigração italiana. Relacionando-se especificamente à imigração italiana, propõe-se, ainda, uma discussão sobre o uso de discursos identitários como estratégia para se desenvolver o turismo rural no contexto do espaço rurbano. ${ }^{1}$

Em termos metodológicos, este artigo é construído a partir de dados empíricos colhidos por meio de levantamento bibliográfico, constituindo-se, portanto, numa pesquisa histórica e empírica.

\section{A imigração europeia no Paraná}

No continente americano, e também no Brasil, a expressão imigração tem sido utilizada para se referir ao período posterior ao advento da independência de um país,

Conceito criado por Graziano da Silva (1999) para tratar das transformações recentes do espaço rural, que ao agregar cada vez mais características do meio urbano, deixaria de ser sinônimo exclusivo de produção agropecuária e incorporaria novas funções por meio das ocupações não agrícolas da população rural. 
embora se possa afirmar que, na América, mesmo que separados por diferentes intervalos temporais, todos são imigrantes, uma vez que não há, neste continente, uma população autóctone ${ }^{2}$ (BALHANA, 1996).

No caso brasileiro, os termos colonização e imigração são adotados para caracterizar contextos históricos diferentes: o primeiro se refere ao momento inicial da ocupação do território, com a imigração destinada à formação de núcleos de povoamento, sobretudo na faixa litorânea, enquanto o segundo se efetiva a partir da independência, quando a ocupação efetiva do solo passou a ser fundamental à soberania nacional e à sua valorização econômica (BALHANA, 1996).

De acordo com Balhana (1996, p. 41), a preocupação com os vazios demográficos faz surgir, na América, "a tradição da porta aberta para os imigrantes de todas as procedências e culturas", diretriz esta apoiada por meio de dispositivos legais que vão dominar esse período histórico da imigração no continente americano. É neste contexto que, no Brasil, se permite a propriedade de terras aos estrangeiros (decreto de 1808) e são fundadas as primeiras colônias de imigrantes: alemães, em Ilhéus (Bahia, 1818), suíços e alemães, em Nova Friburgo (Rio de Janeiro, 1819). Pouco depois, a partir de 1820, formam-se as primeiras colônias alemãs, no Sul do Brasil: São Leopoldo (1824), Três Forquilhas e Torres (1828), no Rio Grande do Sul; São Pedro de Alcântara e Itajaí (1829), em Santa Catarina, e Rio Negro (1829), no Paraná. Assim, observa-se que "o estabelecimento, portanto, da primeira colônia de imigrantes alemães no Paraná se insere em amplo programa de colonização desenvolvido, naquela conjuntura, sob os auspícios do Governo Imperial” (BALHANA, 1996, p. 41).

No entanto, esse primeiro impulso na formação de colônias de imigrantes no Brasil sofre um retrocesso, entre 1830 e 1834, devido ao fracasso de muitos empreendimentos colonizadores, mas é novamente incentivado, a partir de 1834, desta feita, estando a cargo dos governos provinciais. No Paraná, tal política passou a produzir efetivamente resultados, após a emancipação desta província, em 1853 (BALHANA, 1996).

Ressalta-se que, a partir de 1840, a política governamental brasileira de incentivo à imigração deixou de ter o caráter de "preenchimento de vazios demográficos" e passou a se orientar pela necessidade de mão de obra para a agricultura, principalmente para a lavoura cafeeira em expansão (BALHANA, 1996). Enquanto nas demais regiões do Império a imigração tinha por objetivo suprir a carência de mão de obra para a lavoura de exportação,

\footnotetext{
2 Ao considerar a inexistência de população autóctone no continente americano, toma-se por premissa a teoria da origem do homem no continente africano e sua chegada à América por meio da travessia do Estreito de Bering e pelas ilhas da Polinésia.
}

D D D Revista da Associação Nacional de Pós-graduação e Pesquisa em Geografia (Anpege).

D D p.113-138, V.15, n.27, mai./ago. 2019. 
no Paraná, os governantes desenvolveram uma política de imigração diferenciada, uma vez que se buscou formar uma agricultura de abastecimento, estabelecendo-se colônias agrícolas nos arredores dos centros urbanos, sobretudo ao redor da capital, Curitiba (BALHANA, 1996).

\begin{abstract}
A intensiva atividade colonizadora atingiu sobretudo os terrenos dos arredores de Curitiba e, de modo geral, o planalto curitibano, com o estabelecimento de numerosos núcleos coloniais situados a distâncias que variam de dois, três ou mais quilômetros, até um raio de, mais ou menos, trinta quilômetros do centro urbano da Capital paranaense (BALHANA, 1996, p. 46).
\end{abstract}

Na década de 1850, como grande parte da mão de obra escrava deixou as atividades de subsistência para atender à demanda da lavoura cafeeira paulista, gerou-se uma crise de abastecimento de gêneros alimentícios no país, fato que ficou conhecido como "carestia". Assim, a mão de obra imigrante deveria atender à demanda de produção de alimentos, visto que, para o brasileiro (e, especificamente, para o paranaense), o trabalho agrícola era tido como uma atividade de baixo status social (MACHIOSKI, 2004).

É importante destacar que as teorias de diferenciação de raças, que explicavam a desigualdade como inferioridade, nesse contexto histórico, serviram de base para a exclusão da população negra, mesmo após a abolição. Como a miscigenação também era considerada negativa, a solução seria promover "o cada vez mais branco", que resultou numa política de branqueamento da população brasileira (BITTELBRUN, 2016, p. 174). Conforme esta ideologia é que se deve entender o estímulo à ocupação do território brasileiro por meio da imigração europeia, no século XIX. Assim, mediante política pública, sustentada na Lei de Terras de 1850, criaram-se subsídios para estimular a vinda dos imigrantes brancos, que iriam reproduzir a cultura europeia no território nacional. Ao mesmo tempo, negava-se o acesso à terra para a população negra.

No caso do Paraná, de acordo com Priori (2012), a imigração tinha como principal objetivo incentivar o cultivo da agricultura de subsistência, mantendo abastecidos os mercados urbanos que já enfrentavam o raleamento de produtos agrícolas. Esses imigrantes se fixaram sob a condição de colonos, construindo suas próprias casas e formando lavouras com a abertura das matas.

De acordo com Balhana (1996), no Paraná, se desenvolve um sistema de colonização, durante o período provincial, que se baseava numa concepção romântica da imigração estrangeira. Nessa orientação, buscava-se estabelecer uma civilização camponesa à maneira da que ocorria na Europa, derivando desta o modelo de colônias com pequenas propriedades rurais ao redor das cidades, visando, assim, ao abastecimento de gêneros agrícolas para estas. 
Em termos de composição étnica, destaca-se a grande heterogeneidade dos grupos de imigrantes que se estabeleceram nas colônias paranaenses, tais como: os alemães, os italianos e os poloneses, em maior número, e, em menor escala, outros grupos como: os suíços, os franceses e os ingleses (BALHANA, 1996).

Figura 1 - Principais grupos de imigrantes e seu local de estabelecimento no Paraná.

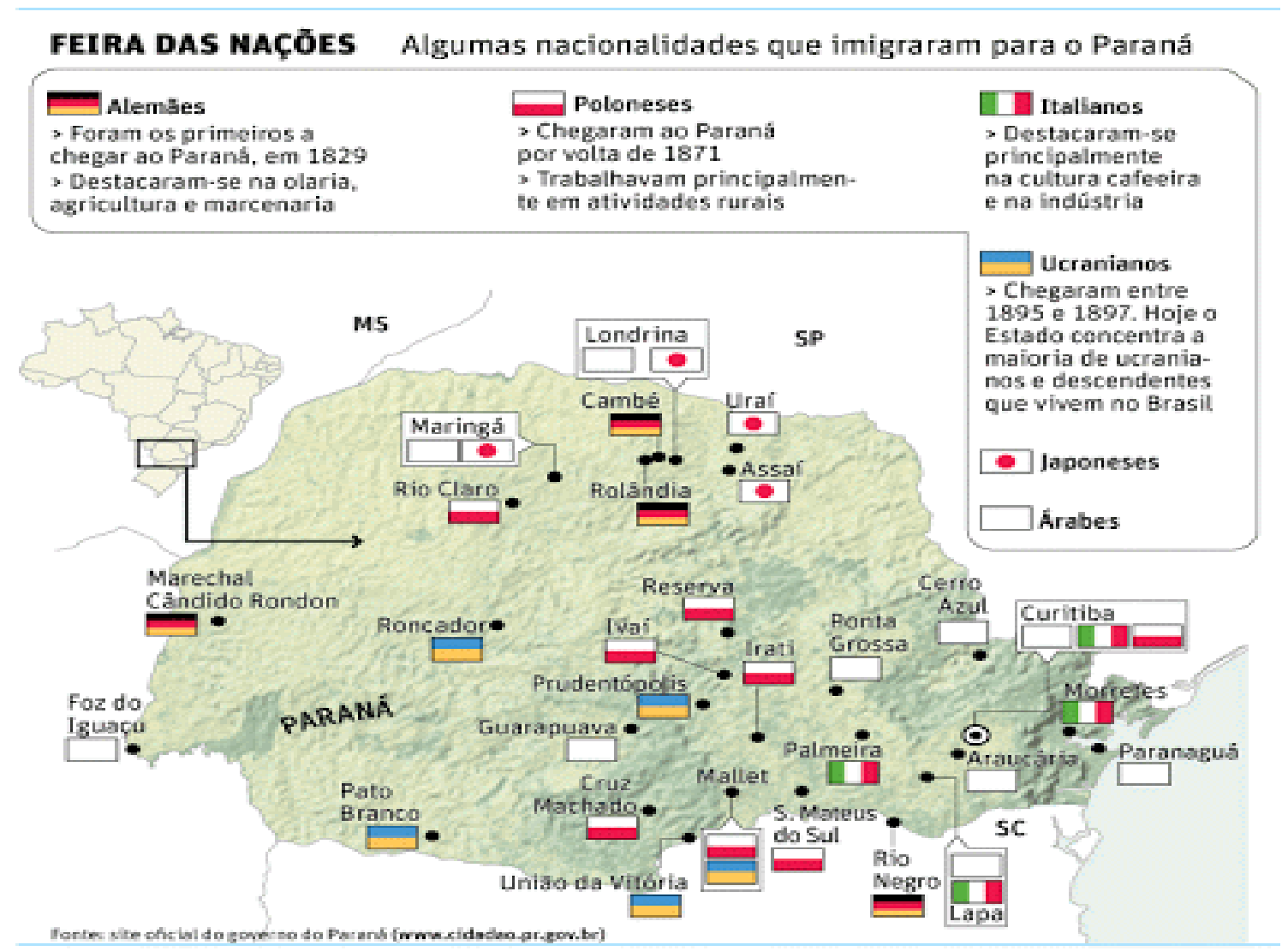

Fonte: Fundação Cultural Gralha Azul. Acesso em: outubro de 2018.

Em média, as colônias paranaenses eram formadas por cerca de 300 imigrantes, e os lotes de terras tinham, em média, 25 hectares por família (OLIVEIRA, 2007).

Para Priori (2012), o processo imigratório, no Paraná, ocorreu de maneira diferenciada em relação aos demais estados do Sul, uma vez que, neste estado, foram poucos os núcleos de colonização que tiveram a presença de apenas uma etnia. A maioria das colônias apresentava, em geral, duas ou mais etnias, o que teria impedido uma colonização mais homogênea, embora os grupos tentassem preservar a sua identidade cultural. Esse autor ressalta, ainda, a contribuição do contingente imigrante no processo de desenvolvimento industrial desse estado, a expansão dos centros urbanos e a difusão de uma cultura de trabalho assalariado.

D

D Revista da Associação Nacional de Pós-graduação e Pesquisa em Geografia (Anpege).

D $D$ p.113-138, V.15, n.27, mai./ago. 2019. 
Desse modo, podemos afirmar que a imigração foi responsável por um processo de transformação social na população paranaense (e, sobretudo, na curitibana), dada a maior concentração desses povos ao redor da capital, engendrando, a partir de sua chegada, novas relações econômicas e sociais neste espaço. De acordo com Wachowicz (2001, p. 159, apud OLIVEIRA, 2007, p. 6), a imigração foi responsável por tornar a sociedade paranaense moderna, e "o Paraná, um estado com população predominantemente branca e com majoritária influência europeia”.

O bom resultado alcançado com as colônias ao redor de Curitiba fez com que esse projeto fosse estendido ao litoral e aos campos gerais, no entanto, os núcleos coloniais aí estabelecidos não alcançaram o mesmo desempenho daqueles do planalto curitibano. Exemplo disto foi a colônia Alexandra (1875), onde se instalou a primeira leva de imigrantes italianos do Paraná, e a colônia Nova Itália (1877). Como estes núcleos não prosperaram, o resultado foi que poucos dos cerca de dois mil e quinhentos imigrantes permaneceram no litoral, e a maioria acabou se transferindo para a região de Curitiba (BALHANA, 1996).

De acordo com Priori (2012), o contraste entre o que se propagava, na Europa, sobre a imigração ao Brasil e a situação real que os imigrantes efetivamente encontravam em terras paranaenses (falta de apoio e de infraestrutura básica e terras inférteis), acabou por levar muitos colonos a abandonarem essa província, sobretudo, entre 1870 e 1880 . Esta situação fez com que, a partir de 1885, “o então Presidente da província, Alfredo d'Escragnolle Taunay, recuperando a política imigratória do Presidente Lamenha Lins, incentivou e subsidiou a vinda de colonos estrangeiros" (PRIORI, 2012, p. 39).

Embora, posteriormente, com o fim da política oficial de colonização com colônias mantidas sob a tutela do governo, na década de 1880, e o estabelecimento de projetos de colonização da iniciativa privada, visando também ao suprimento de trabalhadores para as obras públicas, segundo Balhana (1996), o contingente de imigrantes, no Paraná, foi expressivo, alcançando milhares de imigrantes, até a segunda metade do século XIX.

Entre os diversos grupos de imigrantes que se fixaram no Paraná, se destacam os italianos, cuja principal contribuição inicial ocorreu nas lavouras de café e, posteriormente, se estendeu a outras culturas. Esta presença marca, sobretudo, a ocupação do norte do Paraná, onde "praticamente não há cidade sem a presença dos italianos, que primeiramente se radicaram no Estado de São Paulo e, depois, se transferiam para o Paraná, acompanhando as frentes de ocupação e a cultura do café" (PRIORI, 2012, p. 40-41). Apesar da grande contribuição no processo de ocupação do norte do Paraná, no século XX, verifica-se que "a maior concentração italiana no estado está em Curitiba, na Lapa, no litoral, em Palmeira e, também, em Morretes", 
visto que no litoral e no Planalto Curitibano é que foram fundadas as primeiras colônias de imigrantes italianos, no Paraná, ainda no século XIX (PRIORI, 2012, p. 40-41).

\section{A construção da identidade paranaense e curitibana}

Desde o final do século XIX, têm sido construídas, por escritores e membros da elite intelectual e política paranaense, imagens e metáforas sobre a identidade social e cultural do estado, a partir de diversos textos, estudos e discursos (OLIVEIRA, 2007). Verifica-se em comum, nesses trabalhos, a presença do fundamento étnico como fator de diferenciação do paranaense em relação aos habitantes das demais regiões, assentando-se este, sobretudo, "na figura "branca" do imigrante não português de origem europeia" (OLIVEIRA, 2007, p. 2).

No entanto, é somente no início do século XX, a partir da década de 1920, que surge o "paranismo", definido por Salturi $(2009$, p. 2) como "um movimento integrado em que políticos, intelectuais e artistas envolveram-se com a questão da definição de uma identidade local". Este movimento teve como um dos seus maiores representantes o intelectual Romário Martins, e acompanhou a tendência que havia, na época, em todo o país, de valorização das características regionais. No âmbito do paranismo, se desenvolveu a construção de uma identidade local baseada "em uma visão "branca" e particular da sociedade e do próprio estado do Paraná" (OLIVEIRA, 2007, p. 2-3).

Na segunda metade do século XIX, em um contexto de mudanças no perfil demográfico paranaense, com a venda de escravos para a lavoura cafeeira paulista e a crescente introdução da mão de obra imigrante, surgem "as imagens em torno do caráter benéfico do "imigrante trabalhador", em oposição ao escravo em vias de "desaparecimento"”' (OLIVEIRA, 2007, p. 4). Assim, ao mesmo tempo em que ocorre a construção de um discurso e de um imaginário de valorização dos imigrantes europeus, ocorre também um processo de invisibilização dos demais grupos étnicos, sobretudo, em relação aos negros.

Estudos dos recenseamentos oficiais da população paranaense, nos séculos XVIII e XIX, como os trabalhos de Horacio Gutiérrez, apontam a presença significativa de escravos, no contingente populacional do Paraná. De acordo com Gutiérrez (1988), tais dados revelam que, no período de 1798 a 1830, um a cada cinco habitantes desse estado era escravo. Para 1798 , verificou-se que $23 \%$ da população do litoral eram escrava, enquanto, no planalto, este índice era de 19\%. Em relação à distribuição espacial, constatou-se a correlação entre as populações livre e escrava, sendo que, para todo o período investigado, a primazia demográfica, no Paraná, ficou com Curitiba, seguida de Paranaguá, Antonina e Castro.

D

D Devista da Associação Nacional de Pós-graduação e Pesquisa em Geografia (Anpege).

D D p.113-138, V.15, n.27, mai./ago. 2019. 
De acordo com Gutiérrez (1988), no ano de 1798, 27,6\% da população escrava paranaense residiam em Curitiba. Para o período 1798-1930, os dados indicaram que, embora tenha havido uma ligeira queda da participação da população escrava no montante da população paranaense (de mais de $20 \%$, em 1798 , para $17 \%$, em 1830 ), houve um aumento no número absoluto da população servil. Gutiérrez (1988) aponta ainda que, entre a população escrava paranaense, estavam os negros e os mestiços (mulatos). Desse modo, os dados apresentados confrontam a tese de que tanto a escravidão quanto a população negra não tiveram importância significativa na formação histórica e cultural do Paraná e, especialmente, sobre Curitiba.

De acordo com Moraes e Souza (1999), intelectuais de destaque, como Wilson Martins e Ruy Wachowicz, no século XX, irão atribuir a singularidade do Paraná muito mais à não presença do elemento negro do que propriamente à presença do imigrante europeu: "Assim é o Paraná. Território que, do ponto de vista sociológico, acrescentou ao Brasil uma nova dimensão, a de uma civilização original construída com pedaços de todas as outras. Sem escravidão, sem negro, sem português e sem índio, dir-se-ia que a sua definição humana não é brasileira” (MARTINS, 1989, p. 446 apud MORAES, SOUZA, 1999, p. 10). Para estes autores, a imigração e a inexistência da grande escravatura serão os aspectos a serem ressaltados, na história social paranaense contada a partir de então, salvo algumas exceções, como no trabalho de Octavio Ianni (As metamorfoses do escravo, 1962), que destaca o processo de escravidão, tanto a indígena, quanto a negra, no Sul do Brasil.

Desse modo, no século XX, a imigração europeia (não portuguesa) passa a ser identificada como uma das características definidoras da identidade local, o que é reforçado, posteriormente, na obra Um Brasil diferente, de Wilson Martins, publicada em 1955, e na apropriação desse discurso pela elite intelectual e pela política paranaense (OLIVEIRA, 2007). Essa obra foi inspirada em Casa-grande \& senzala, mas, para Wilson Martins, o Paraná seria diferente do Brasil descrito por Gilberto Freyre por não ter conhecido o processo de escravidão, sugerindo "a existência de um homem paranaense, formado por "elementos polonês, ucranianos, alemão, italiano" e os "pequenos grupos", o índio e o negro, estes últimos em proporção praticamente insignificante" (VIACAVA, 2009, p. 5).

No caso específico dos grupos indígenas, Mota (2008) aborda o discurso do "vazio demográfico", disseminado por diversos agentes sociais e que negava a existência e a ocupação do espaço paranaense por comunidades indígenas, desconsiderando e invisibilizando estes povos que, segundo estudos históricos e arqueológicos, já habitavam o território paranaense havia milhares de anos. 
Os agentes dessa projeção são vários: a história oficial das companhias colonizadoras; as falas governamentais e sua incorporação nos escritos que fazem a apologia dessa colonização exaltando seu pioneirismo; os geógrafos que escreveram sobre a ocupação nas décadas de 30 a 50 do século XX; a historiografia sobre o Paraná produzida nas universidades e, por fim, os livros didáticos, que são uma síntese das três fontes, repetindo para milhares de estudantes do Estado a ideia da região como um imenso vazio demográfico, até o início da década de 30 deste século, quando começa, então, a ser colonizada (MOTA, 2008, p. 19-20).

Para Reis e Rodrigues (2016), até o começo da década de 1980, as narrativas referentes à história e à cultura indígenas, produzidas pelos grupos dominantes, tinham por objetivo negar a presença indígena e esconder a violência utilizada para iniciar o processo de colonização, pois, desse modo, seria possível justificar a dominação imposta como algo necessário para o desenvolvimento do progresso. A construção deste discurso acabou por distorcer "a história e cultura dessas populações e ainda promoveram ideias de racismo e preconceitos" (REIS, RODRIGUES, 2016, p. 14).

Contrariando o discurso oficial, estudos como os de Mota (2008) comprovam a presença indígena em território paranaense, desde muito antes da introdução dos imigrantes europeus para a ocupação dos chamados vazios demográficos.

Porém, conforme relatos dos viajantes, relatórios de expedições militares, científicas e governamentais e ofícios da burocracia governamental, os índios estavam presentes em todas as partes do Estado. Essas evidências contrariam a ideia de um Paraná desabitado. Contrariam a construção do vazio demográfico que apagou da história regional a presença indígena (MOTA, 2008, p. 76).

Assim, também os grupos indígenas foram invisibilizados no discurso identitário do paranismo e, posteriormente, na construção simbólica da Curitiba moderna, embora, contraditoriamente, o próprio nome da cidade tenha origem indígena (Guarani): kur yt yba quer dizer "grande quantidade de pinheiros, pinheiral".

Em 1992, com a eleição de Rafael Greca de Macedo como prefeito de Curitiba, assiste-se a uma retomada, sob o viés do marketing político, da preocupação de se reforçar o papel do imigrante europeu na formação de Curitiba. Ressalta-se que esta preocupação já havia sido expressa na gestão de Jaime Lerner (1971), do qual Greca pode ser considerado herdeiro político (MORAES, SOUZA, 1999).

No entanto, as discussões sobre a identidade social da capital paranaense remetem ao início do século XX.

D

D Devista da Associação Nacional de Pós-graduação e Pesquisa em Geografia (Anpege).

D $D$ p.113-138, V.15, n.27, mai./ago. 2019. 
Desde o início do século XX Curitiba presenciou um forte movimento em torno da definição de sua identidade cultural e étnica. Desde então, proliferam-se evidências de uma demanda crescente por ações reafirmadoras, solidificadoras do estatuto de uma cidade que se pensa moderna, elegante, europeia. Mais recentemente, Curitiba procura se assumir como um protótipo de cidade multicultural (VIACAVA, 2009, p. 8).

Assim, Greca deu continuidade à política de valorização étnica europeia por meio da atuação da Fundação Cultural de Curitiba e de diversas atividades, como a inauguração de obras e monumentos em homenagem às etnias, a promoção de feiras gastronômicas e de apresentações folclóricas e, ainda, a produção da série de livros Lições curitibanas, destinados aos estudantes das séries iniciais do município (MORAES, SOUZA, 1999).

De forma clara, sempre acompanhada de imagens, estes livros vão construindo a "imagem" da cidade de Curitiba, sempre enfatizada a presença dos imigrantes europeus. Quando encontramos citações sobre a escravidão, o assunto sugere a escravidão no âmbito nacional e não na cidade. Além de fotos da época, a arquitetura da cidade recebe um destaque especial mostrando a influência dos imigrantes (MORAES, SOUZA, 1999, p. 13).

De acordo com os autores acima citados, merece também destaque outra iniciativa de Rafael Greca: a publicação de antigos e de novos autores que tratam do Paraná, entre eles, alguns clássicos paranistas como Romário Martins, com a Coleção Farol do Saber. Assim, as estratégias acima apontadas foram utilizadas para se criar o "ideário de que Curitiba seja uma "cidade europeia", "capital de todos os povos"”' (MORAES, SOUZA, 1999, p. 13).

A construção dessa imagem para a capital paranaense, de acordo com Moraes e Souza (1999, p. 13), rendeu dividendos políticos a Rafael Greca e se saiu efetivamente vitoriosa, "porque partiu da crença destes de que a imagem e a cidade que construíram era real". Materializou-se, desse modo, esse simbolismo por meio de monumentos e livros, entre outros, tornando-se, assim, "uma peça de realidade cada vez mais inquestionável" (MORAES, SOUZA, 1999, p. 13).

Nesse cenário de "capital das etnias", o contraditório é justamente perceber que a população negra foi e continua sendo marginalizada - ou melhor, invisibilizada. Praticamente, não há monumentos em Curitiba em homenagem à contribuição negra em sua formação demográfica, ou, quando existe, este marco passa despercebido na paisagem urbana, como no caso da placa de bronze dedicada à colônia afro-brasileira, na praça Santos Andrade, e da praça Zumbi dos Palmares, no Pinheirinho. Situação oposta a dos marcos dos imigrantes europeus, que se encontram perfeitamente integrados aos circuitos turísticos da cidade (MORAES, SOUZA, 1999). 
Segundo Stollmeier e Oliveira (2015), Curitiba apresenta um amplo conjunto de homenagens simbólicas à sua composição multicultural, materializado, sobretudo, nos equipamentos de lazer, tais como a praça da Espanha (1955), a praça da Ucrânia (1967), o bosque Alemão (1996), o Memorial Árabe (1996), o bosque de Portugal (1994), o bosque Italiano (1990), a praça do Japão e o Parque do Centenário da Imigração Japonesa (2012), entre outros. Cabe ainda destacar que, ao construir uma identidade positiva de integração étnica, grupos que inicialmente foram marginalizados na sociedade paranaense e curitibana (como poloneses e japoneses) passaram a servalorizados, e, embora continuem a representar estatisticamente um grupo muito menor do que a comunidade negra, possuem, atualmente, um lugar de destaque, com praças e monumentos em sua homenagem, na capital do estado (MORAES, SOUZA, 1999).

Essa situação nos faz refletir sobre a relação entre a imagem criada para Curitiba (a capital das etnias) e a cidade real, que marginaliza e invisibiliza os grupos que não interessam para a manutenção de sua identidade europeia. Os negros de ontem e de hoje, incluindo-se os novos imigrantes (como os haitianos, que têm sofrido com atos de violência simbólica e física), como apontam Stollmeier e Oliveira (2015), continuam esquecidos, na capital mais europeia e branca do Brasil.

\section{Os italianos em Curitiba e na Região Metropolitana}

A política imigratória desenvolvida na província do Paraná, no século XIX, tinha por objetivo a criação de núcleos coloniais voltados para a agricultura de abastecimento, o que atraiu uma diversidade de imigrantes europeus, onde se destacaram, em termos de densidade, os seguintes grupos: poloneses $(49,2 \%)$, ucranianos $(14,1 \%)$, alemães $(13,3 \%)$, italianos $(8,9 \%)$ e outras etnias (apenas 14,5\%). Tratando-se especificamente dos italianos, ressaltase que estes começaram a chegar, em grandes levas, a partir de 1875 (MACHIOSKI, 2004).

Os contextos histórico e econômico em que se desenvolve o intenso fluxo de italianos para o Brasil envolvem o avanço do capitalismo e a transição demográfica na Europa. O excedente populacional, fruto da diminuição da taxa de mortalidade e manutenção dos elevados índices de natalidade nesse continente, não era absorvido no mercado de trabalho urbano, ao mesmo tempo em que, no campo, os pequenos proprietários e arrendatários eram expulsos com o avanço do capitalismo (MACHIOSKI, 2004).

\footnotetext{
Isso se explica pela forma como ocorreu a penetração capitalista no campo: concentração da propriedade; altas taxas de impostos sobre a terra, que impeliram o pequeno proprietário a empréstimos e ao consequente endividamento; oferta, pela grande propriedade, de produtos a preços inferiores no mercado, eliminando a concorrência do pequeno agricultor; e, finalmente, a sua transformação em mão-de-obra para a indústria nascente (ALVIM, 1986, p. 23).
}

D

D Devista da Associação Nacional de Pós-graduação e Pesquisa em Geografia (Anpege).

D $D$ p.113-138, V.15, n.27, mai./ago. 2019. 
Para Machioski (2004), o imigrante italiano que primeiro chegou ao Brasil tinha suas origens na pequena propriedade rural familiar e almejava conquistar, neste país, um pedaço de terra que assegurasse sua independência e sobrevivência, garantindo a reprodução de um modo de vida semelhante ao que ele possuía na Itália. Assim, o Paraná apresentava condições ideais para a instalação de colônias italianas, uma vez que a política imigratória visava à formação de uma agricultura de abastecimento, além de apresentar clima e solo muito semelhantes aos encontrados em território europeu (MACHIOSKI, 2004).

Os imigrantes italianos que vieram para o Brasil, no século XIX, partiam do porto de Gênova e desembarcavam na ilha das Flores, na baía de Guanabara (Rio de Janeiro), local em que todos os demais imigrantes europeus desembarcavam, e de onde, após a realização de registros e exames médicos, eram enviados para as províncias (MACHIOSKI, 2008). Na Província do Paraná, esses imigrantes chegavam ao porto D. Pedro II, em Paranaguá, onde novamente eram registrados e, em seguida, encaminhados para hospedarias nesta cidade, em Antonina e em Morretes, cidades localizadas no litoral paranaense.

As primeiras colônias de italianos em território paranaense foram fundadas em Morretes, mas, apesar da terra fértil e da abundância de água nesta cidade, muitos colonos não se adaptaram às condições climáticas (temperatura e umidade elevadas) do local e acabaram migrando para o planalto (MACHIOSKI, 2008).

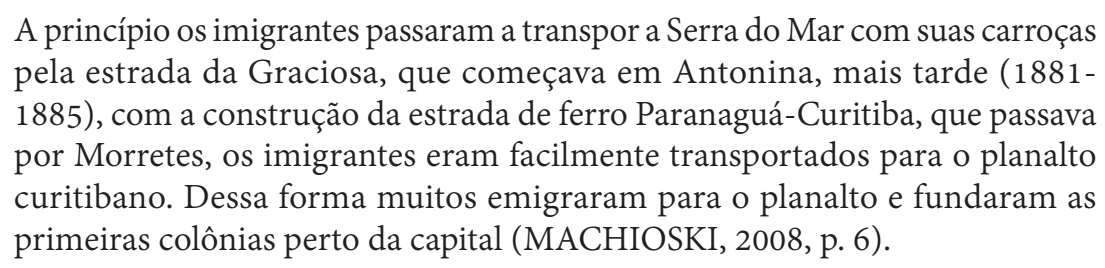

É importante ressaltar também a contribuição dos italianos na construção da estrada de ferro Paranaguá-Curitiba (1880-1885), o que atendia a um dos interesses do Império em relação ao papel dos imigrantes, isto é, a sua atuação como trabalhadores em grandes obras públicas (BALHANA, 1996).

Em 1875, com a chegada da primeira leva de imigrantes italianos, no Paraná, foi fundada, pelo empresário de colonização Sabino Tripotti, a colônia Alexandra. Tal empreendimento não obteve sucesso, pois, juntamente com o problema da adaptação climática, relata-se que havia também problemas relacionados à má administração da colônia, uma vez que o mencionado empresário não estava preocupado com o estabelecimento dos imigrantes, mas somente em obter lucros, atraindo o maior contingente possível destes trabalhadores (MACHIOSKI, 2004). 
Para acolher os imigrantes que se recusavam a ficar em Alexandra, o governo provincial fundou a colônia Nova Itália, cuja sede estava em Morretes, e que englobava o total de doze núcleos coloniais, estendendo-se até Antonina. Porém, isto não foi o suficiente para estimular a fixação desses imigrantes no litoral, o que levou o governo, atendendo aos interesses de fomentar o abastecimento urbano de gêneros agrícolas, a apoiar aqueles que desejavam migrar para o planalto, fundando-se, assim, as primeiras colônias de italianos na região de Curitiba (MACHIOSKI, 2004).

Esse programa colonizador visava implantar colônias agrícolas nas proximidades dos centros urbanos, com o objetivo de colocá-las em contato com os mercados consumidores. Assim, nos arredores de Curitiba foram instalados numerosos núcleos coloniais situados a distâncias que variavam de 2 quilômetros até 30 quilômetros do centro urbano da capital paranaense (MACHIOSKI, 2004, p. 16).

Entre as colônias de imigrantes italianos instaladas no planalto curitibano, algumas acabaram por dar origem aos atuais municípios da Região Metropolitana de Curitiba (RMC), tais como: Antônio Rebouças (Campo Largo), Novo Tirol (Piraquara), Murici e Inspetor Carvalho (São José dos Pinhais), Alfredo Chaves (Colombo) e outros (MACHIOSKI, 2008).

De acordo com as informações no portal eletrônico da Prefeitura de Curitiba (www. curitiba.pr.gov.br), as colônias de imigrantes também deram origem a muitos bairros curitibanos, com destaque para o bairro de Santa Felicidade (formado a partir da colônia Santa Felicidade, fundada em 1878), atual polo gastronômico italiano nesta capital. Outros bairros que tiveram sua origem ligada às colônias italianas são Água Verde, Pilarzinho e Umbará. Os imigrantes italianos, em Curitiba, dedicaram-se à atividade agrícola e, posteriormente, também ao comércio e à indústria.

Destacam-se, na paisagem urbana de Curitiba, muitos marcos em homenagem à imigração italiana, tais como: o Memorial da Imigração Italiana em Curitiba, localizado no bosque São Cristóvão (Figura 2); o portal do bairro Santa Felicidade (Figura 3); o Monumento ao Centenário da Imigração Italiana (Figura 4); os imóveis com inspiração italiana em sua arquitetura, como a Igreja do Umbará (Figura 5), e, ainda, o Palácio Giuseppe Garibaldi (Figura 6), sede da Sociedade Garibaldi, fundada, em 1883, para agregar os imigrantes italianos em Curitiba; e o próprio bairro Santa Felicidade, polo gastronômico da cultura italiana nesta cidade.

D

D Devista da Associação Nacional de Pós-graduação e Pesquisa em Geografia (Anpege).

D D p.113-138, V.15, n.27, mai./ago. 2019. 
Figura 2 - Memorial da Imigração Italiana de Curitiba, no bosque São Cristóvão, em Santa Felicidade.

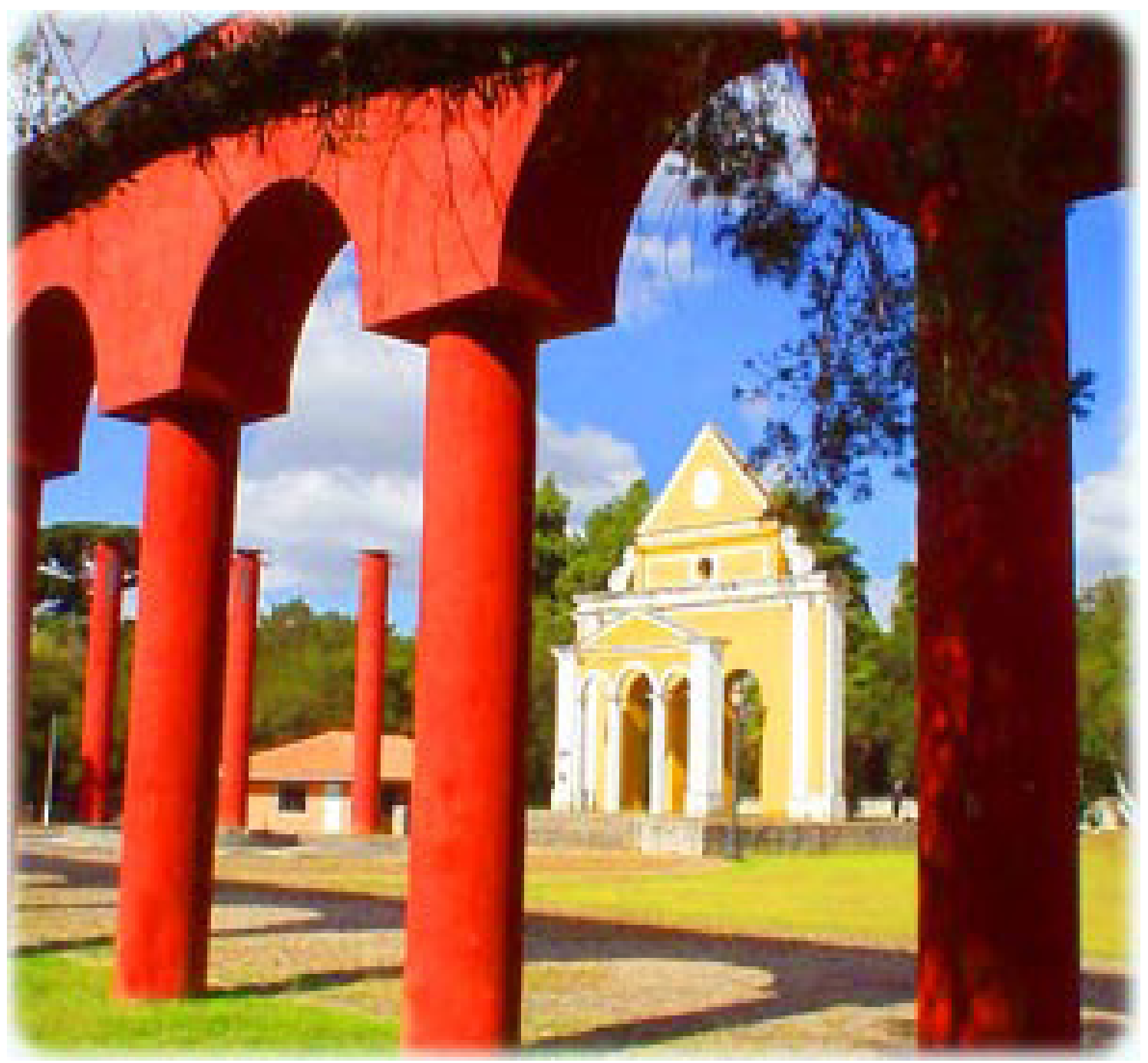

Fonte: Guia Geográfico Curitiba. Acesso em: maio de 2017.

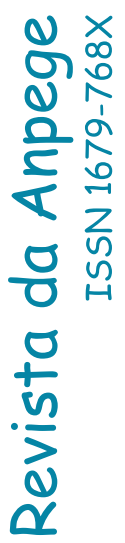

a

Revista da Associação Nacional de Pós-graduação e Pesquisa em Geografia (Anpege). p.113-138, V.15, n.27, mai./ago. 2019. 
Figura 3 - Portal de Santa Felicidade, bairro tradicional da cultura italiana, em Curitiba/PR.

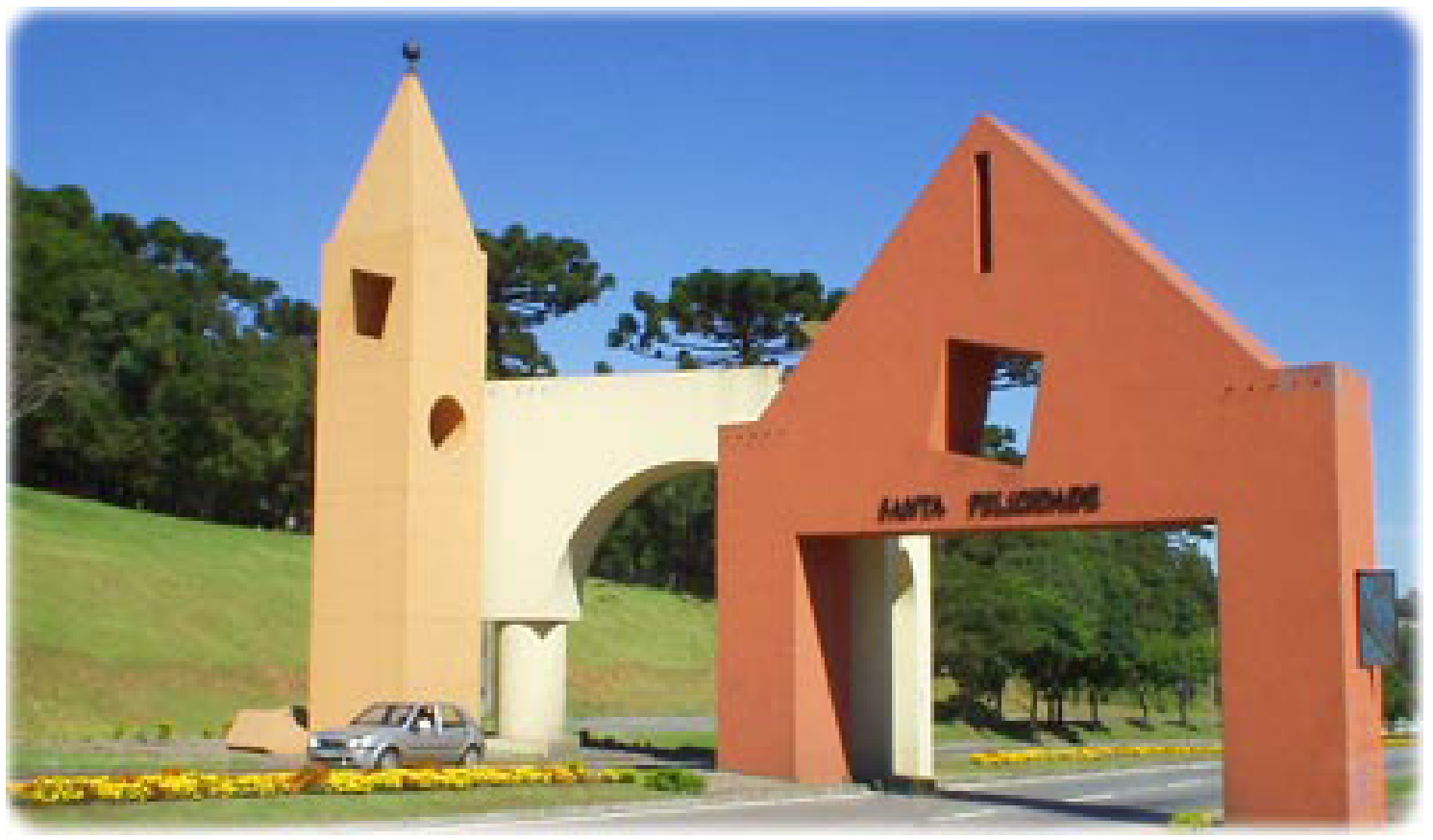

Fonte: Guia Geográfico Curitiba. Acesso em: maio de 2017.

Figura 4 - Monumento ao Centenário da Imigração Italiana, na avenida Manoel Ribas, em Santa Felicidade, Curitiba/PR.
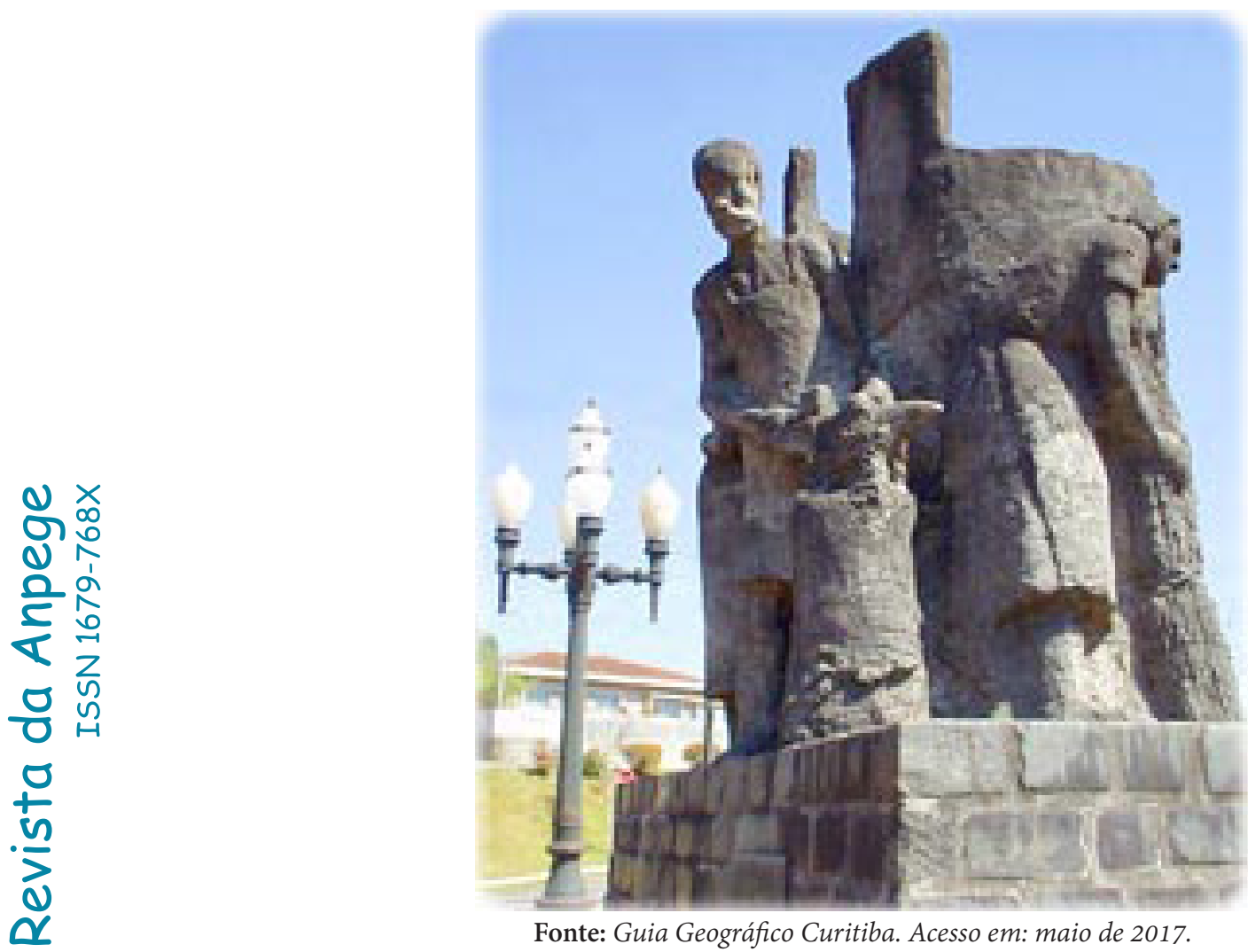

Fonte: Guia Geográfico Curitiba. Acesso em: maio de 2017.

D

D D Revista da Associação Nacional de Pós-graduação e Pesquisa em Geografia (Anpege).

$D$ D p.113-138, V.15, n.27, mai./ago. 2019. 
Figura 5 - Igreja de São Pedro, concluída em 1938, no bairro Umbará, em Curitiba/PR. Arquitetura de inspiração italiana.

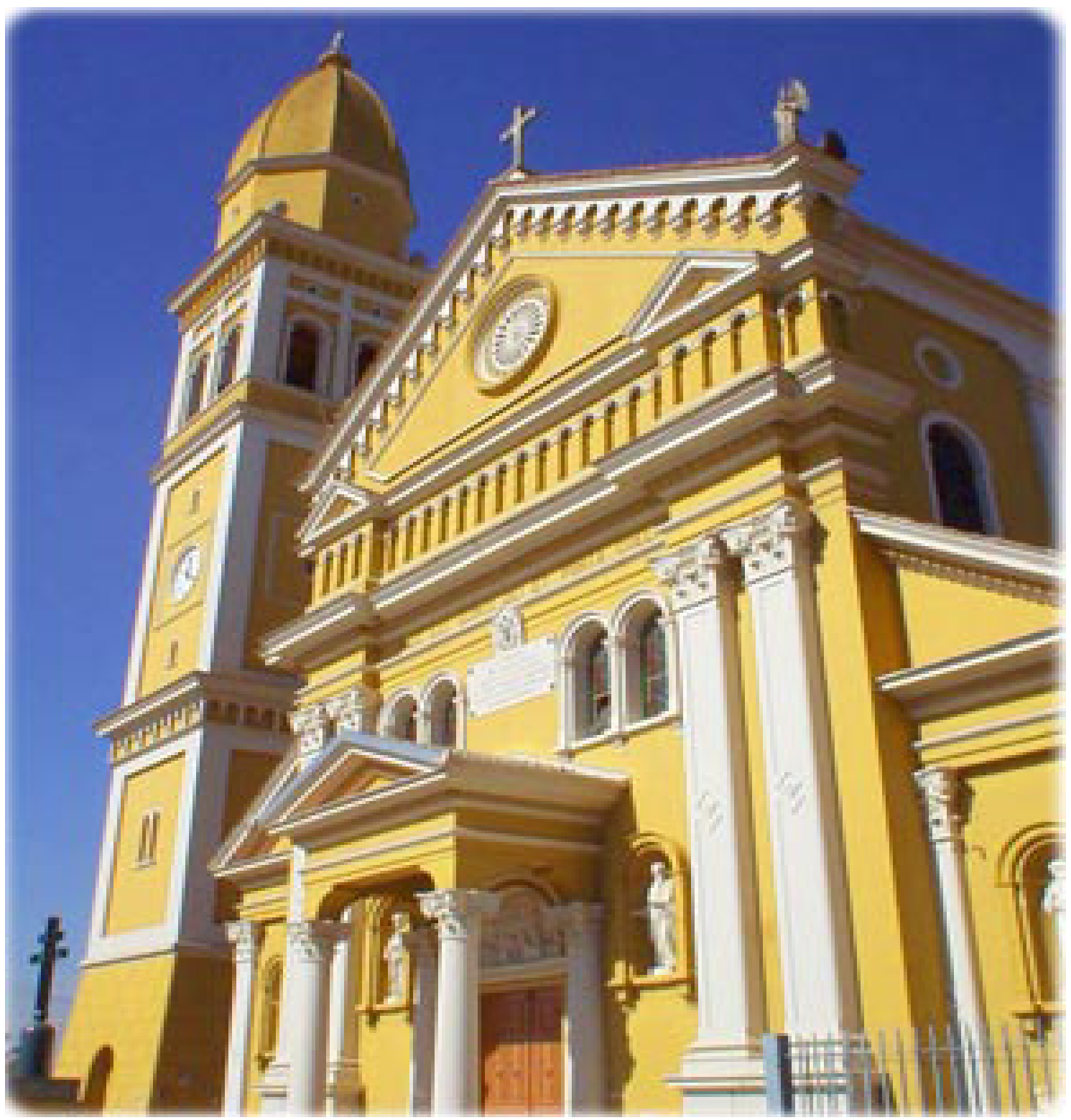

Fonte: Guia Geográfico Curitiba. Acesso em: maio de 2017.

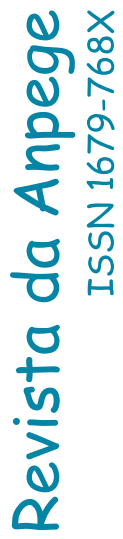


Figura 6 - Palácio Giuseppe Garibaldi, sede da Sociedade Garibaldi, localizado na praça Garibaldi, em Curitiba/PR.

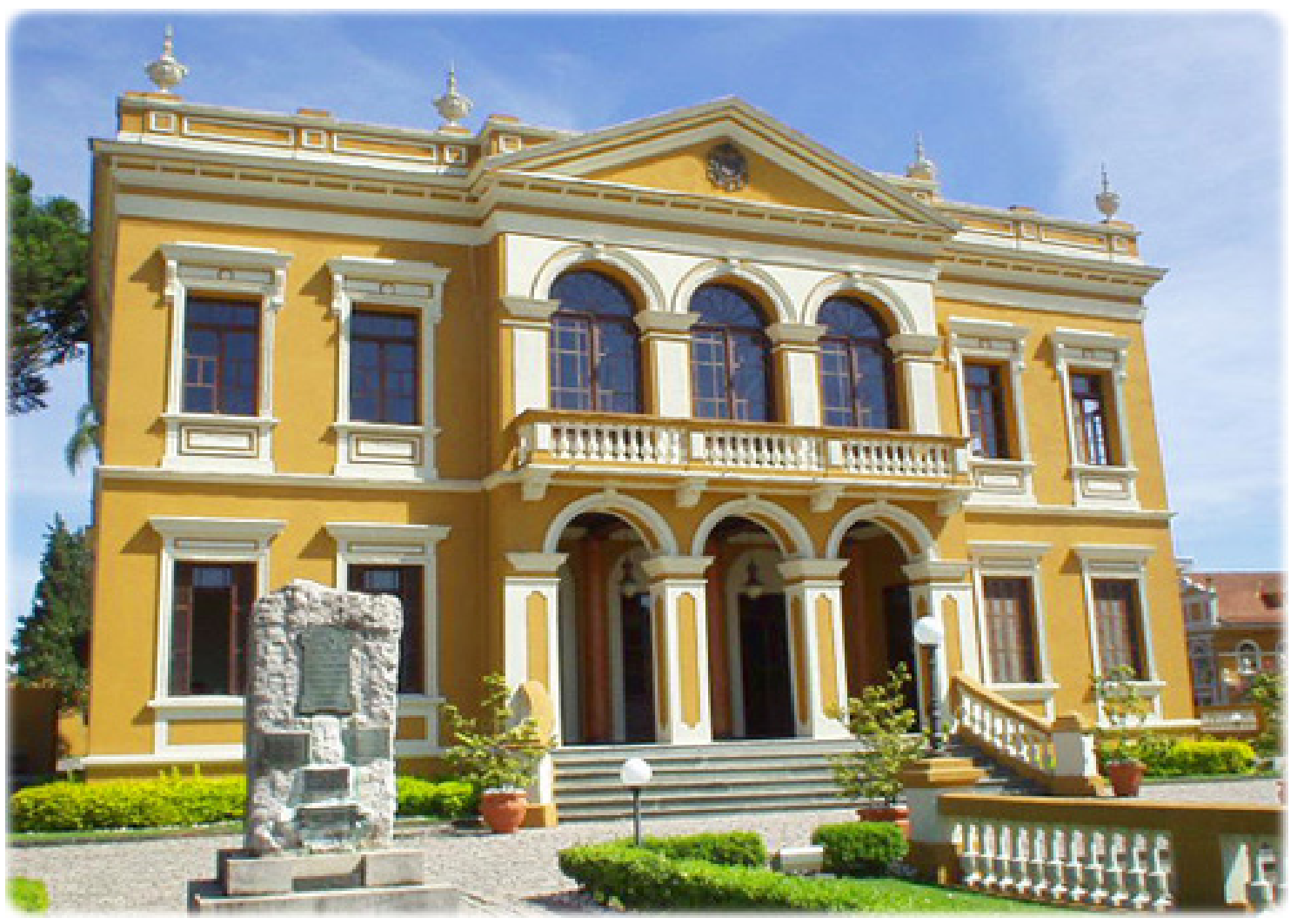

Fonte: Guia Geográfico Curitiba. Acesso em: maio de 2017.

\section{A colônia Mergulhão}

Localizada na Região Metropolitana de Curitiba (RMC), no município de São José dos Pinhais, a colônia Mergulhão é um exemplo de comunidade originária das colônias de imigrantes fundadas no anel metropolitano, entre a segunda metade do século XIX e a primeira metade do século XX, para atender à demanda urbana por gêneros alimentícios.

A origem dessa colônia remonta a um grupo de imigrantes italianos que se deslocaram do litoral, provavelmente das colônias de Morretes, e se fixaram nessa área, onde derrubaram a vegetação nativa, construíram suas casas e passaram a cultivar a terra. O nome da comunidade, Mergulhão, remete à designação de um pássaro comum e abundante na área, que se alimenta de peixes "pescados" por meio do voo rasante e do mergulho nas águas de rios e lagos (CORONA, 2011).

D 
De acordo com Corona (2011), a colônia Mergulhão é formada por agricultores familiares, ${ }^{3}$ descendentes de imigrantes italianos e poloneses, que residem em lotes pequenos e médios - a maioria apresenta entre 10 e 20 ha -, e desenvolvem atividades ligadas à olericultura, à fruticultura, à pecuária e à produção de leite e de vinho.

A trajetória produtiva das famílias da comunidade de Mergulhão é dividida, segundo Corona, em três momentos distintos:

\begin{abstract}
Em síntese, a trajetória das famílias dessa comunidade pode ser sintetizada em três grandes fases: a primeira, com base na herança camponesa europeia baseada na policultura-criação e na mecanização com tração animal que marcou a ocupação e o desenvolvimento da comunidade; a segunda, com base na intensa produção leiteira, mais especializada e tecnificada, com grande prosperidade econômica; a fase atual, marcada pela olericultura/fruticultura e pelo turismo rural, o qual fez intensificar a produção tradicional do vinho e de outros derivados da produção tradicional em agropecuária, ao mesmo tempo modificando aspectos importantes da vida comunitária (CORONA, 2011, p. 147).
\end{abstract}

É importante salientar que tanto a introdução da produção leiteira moderna, quanto as atividades de turismo rural são frutos da intervenção de políticas públicas, orientadas, sobretudo, pela Coordenação da Região Metropolitana de Curitiba (COMEC), por meio do Plano de Desenvolvimento Integrado (PDI) para a região metropolitana: "Em 1978, no primeiro Plano de Desenvolvimento Integrado (PDI), a COMEC recomendava para a região a leste de Curitiba a constituição e expansão da bacia leiteira para abastecer a RMC" (CORONA, 2011, p. 146).

Por sua vez, a introdução das atividades de turismo rural remonta à orientação do segundo PDI (2002/2003), em que a COMEC buscou evidenciar as preocupações ambientais, sobretudo em relação aos recursos hídricos, incorporando a temática do desenvolvimento sustentável. Como a porção leste da região metropolitana (área em que se localiza a colônia Mergulhão) é uma área estratégica para a captação de água, a recomendação foi a de que ali se desenvolvessem atividades com menor impacto ambiental (CORONA, 2011).

Tal preocupação se fortaleceu, com a criação da Área de Proteção Ambiental (APA) Estadual do Rio Pequeno (Decreto 1752, de 6/5/1996), que fica à margem da comunidade de Mergulhão. A partir deste momento, os poderes públicos municipal e estadual desenvolveram atividades para estimular o turismo rural nesta região. Exemplo disto foi a criação do circuito turístico "Caminho do Vinho", no início dos anos 2000 (CORONA, 2011).

\footnotetext{
3 A agricultura familiar é entendida por Wanderley (1999) como aquela em que a família, ao mesmo tempo em que é proprietária dos meios de produção, assume o trabalho no estabelecimento produtivo.
} 


\begin{abstract}
A Prefeitura Municipal tem participação em diversas ações: pavimentação das vias de acesso e das que ficam no interior da comunidade; reuniões e incentivo para a constituição da Associação do Caminho do Vinho; distribuição de placas do "caminho do vinho" na frente das cantinas; pesque-pagues; restaurantes; venda de artesanato, com indicação da atividade e a família responsável; infraestrutura para a realização da festa do vinho; entre outras. O que era uma tradição - a uva e o vinho e as "miudezas" - agora passa a ser o maior atrativo para o turismo rural, responsáveis por ganhos significativos para as famílias envolvidas. $\mathrm{O}$ vinho passou a ser uma marca da comunidade, mas, em torno dele, outras atividades foram sendo desenvolvidas para aproveitar o fluxo dos turistas. Exemplo são os restaurantes, cafés coloniais, pesque-pagues e venda de artesanato (os dados da renda familiar apresentados mais à frente permitem identificar a importância dessas atividades) (CORONA, 2011, p. 148).
\end{abstract}

Verifica-se também o importante papel da Prefeitura de São José dos Pinhais de fomentar o turismo rural apoiado na temática imigratória. Como exemplo desta estratégia, apontam-se os materiais publicitários utilizados para a divulgação do "Caminho do Vinho" (onde se localiza a colônia Mergulhão) e o "Caminho das Colônias", conforme as figuras que seguem:

\title{
Figura 7 - Folheto de divulgação do Caminho das Colônias, em São José dos Pinhais/PR.
}

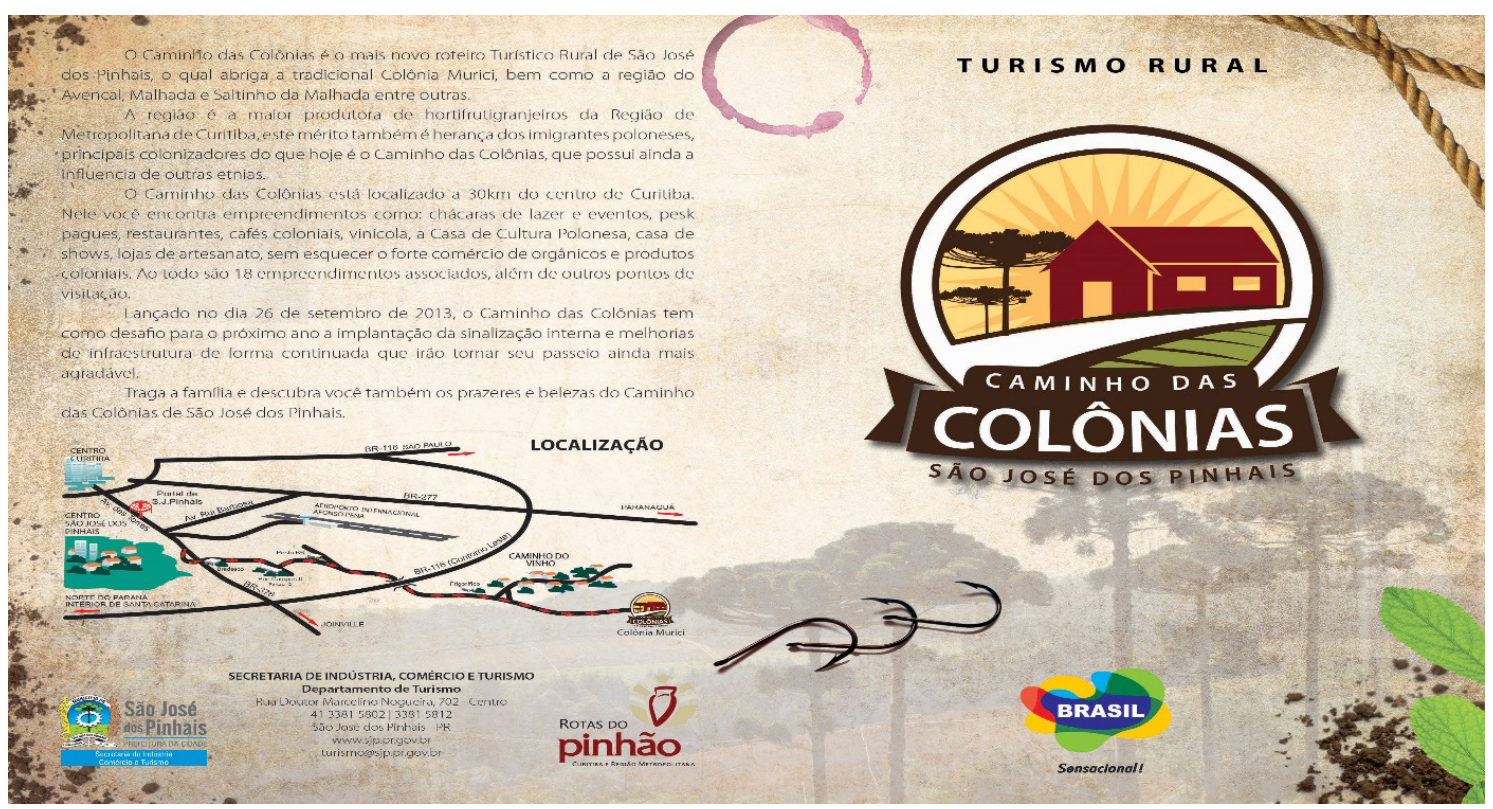

Fonte: Secretaria Municipal de Indústria, Comércio e Turismo de São José dos Pinhais. Acesso em: outubro 2018. 
Figura 8 - Folheto de divulgação do Caminho do Vinho, em São José dos Pinhais/PR.

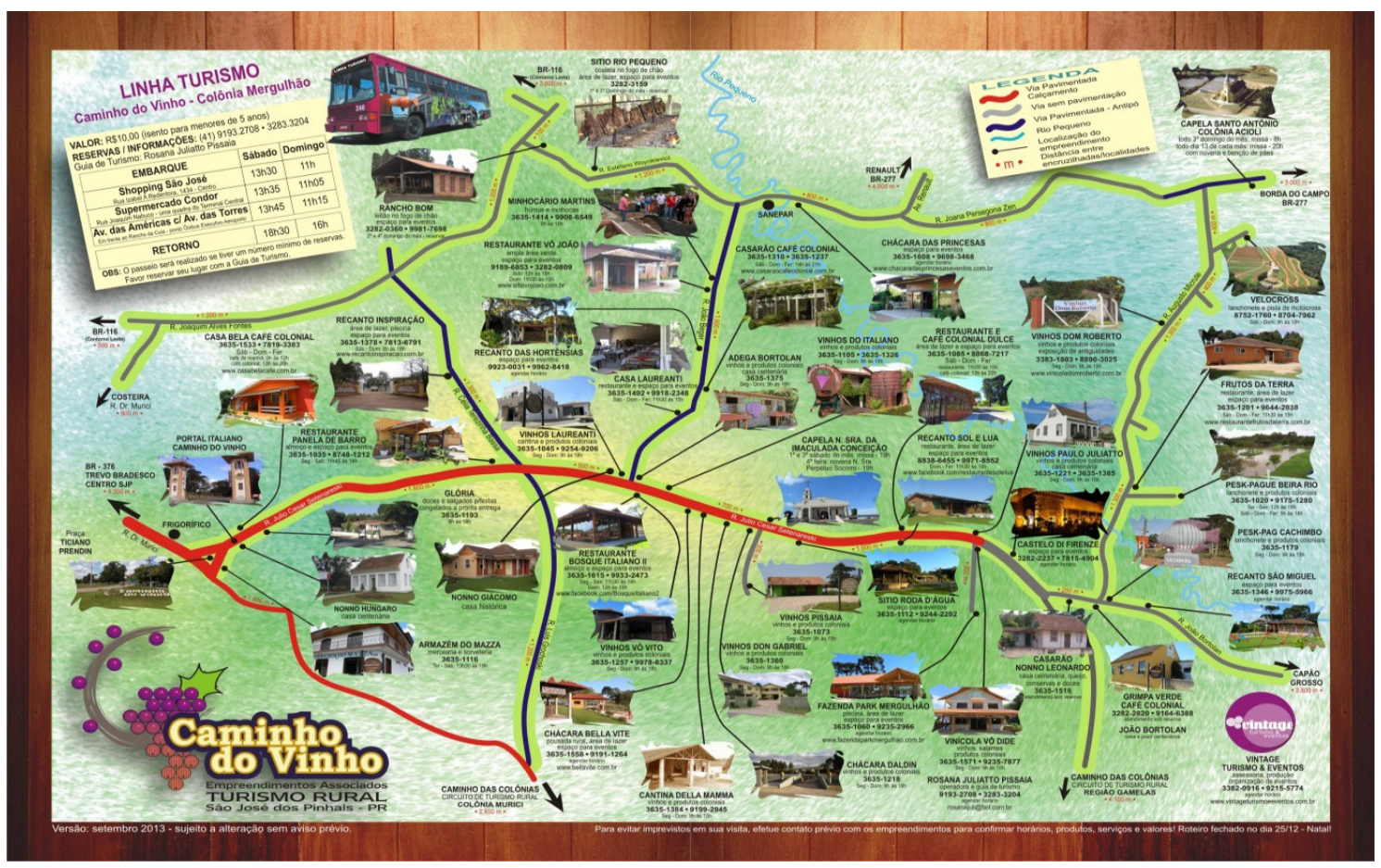

Fonte: Secretaria Municipal de Indústria, Comércio e Turismo de São José dos Pinhais. Acesso em: outubro 2018.

$\mathrm{Na}$ atualidade, portanto, a agricultura familiar presente na colônia Mergulhão continua associada à produção agropecuária, porém, as atividades pluriativas, ${ }^{4}$ relacionadas sobretudo com a demanda do turismo rural, correspondem cada vez mais a significativa parcela da renda familiar, o que, devido à localização privilegiada deste espaço (a cerca de $25 \mathrm{~km}$ distante do centro de Curitiba e a aproximadamente 6km de São José dos Pinhais) e à existência de uma boa estrutura viária, se torna uma estratégia viável para a sobrevivência e a reprodução dessas famílias. Segundo Corona (2011, p. 150), “a maioria das famílias envolvidas com o "caminho do vinho" está investindo na construção e em equipamentos mais adequados para a produção do vinho e dos demais produtos artesanais, bem como na comercialização direta com os consumidores”.

Verifica-se também a introdução da agricultura ecológica, na colônia Mergulhão, abrangendo poucas famílias, até então, como retrata Corona (2011, p. 151), o que evidencia uma estratégia de sobrevivência da produção familiar frente “à lógica de mercado, porque

\footnotetext{
4 A pluriatividade é um fenômeno que resulta da combinação entre ocupações agrícolas e não agrícolas dos membros que compõem uma família (SCHNEIDER, 2007). A pluriatividade foi o foco do programa "Vilas Rurais", criado pelo governo estadual do Paraná, no final da década de 1990, e analisado em estudo de Zafalon (2015), em que se constatou que a pluriatividade deve ser entendida como um fator positivo no espaço rurbano, pois é responsável por elevar a renda e melhorar as condições de vida das famílias.
} 
reduz custos e melhora os preços na comercialização; às pressões para a conservação ambiental e preservação da paisagem rural porque são possibilidades de atrair os turistas".

A análise dos dados demográficos realizada por Corona (2011) mostra um envelhecimento da população residente na colônia Mergulhão, o que favorece o movimento de retorno e mesmo de permanência de filhos e netos desses agricultores, reforçando os relatos levantados por esta autora, que apontam o interesse dos moradores pela preservação e pela ampliação do turismo rural combinadas com a continuidade da olericultura e da fruticultura, mas voltadas para uma "produção mais natural". Portanto, a permanência dessas famílias de agricultores "depende da combinação das atividades agropecuárias e do turismo rural, com forte presença da pluriatividade" (CORONA, 2011, p. 152). Este fato é comprovado pelos levantamentos de origem da renda familiar, por meio dos quais se verificou o seguinte:

Observando quais são as fontes que compõem a renda monetária familiar verificase que: das 22 famílias de Mergulhão - 6 têm mais de $80 \%$ da renda oriunda da produção agropecuária (14 têm alguma renda da produção agropecuária); 3 das 5 cantinas de vinho têm mais de $70 \%$ da renda desta origem, 1 tem $43 \%$ e o outro apenas $3 \%$ porque tem no estabelecimento uma oficina mecânica que rende $90 \%$ do total dos ganhos familiares; 4 têm mais de $50 \%$ da renda oriunda de aposentadoria (13 aposentados); 1 família obtém $71 \%$ da renda com o pesque-pague; 1 família obtém $68 \%$ da renda do salário da esposa e filhas; 1 família obtém $65 \%$ da renda de aluguel de imóveis; e 1 tem $50 \%$ da renda oriunda da produção agrícola e 50\% do trabalho assalariado do responsável em trabalho agrícola externo. Esses dados comprovam a importância da produção agropecuária e da pluriatividade das famílias (CORONA, 2011, p. 152).

De fato, se verifica uma intensa ligação da colônia com o meio urbano, e as atividades de comércio e lazer ofertadas pelo circuito do vinho, com intenso fluxo de visitantes de Curitiba e região metropolitana, tornam este espaço um exemplo de espaço rurbano, como proposto por Graziano da Silva (2001). Desse modo, a pluriatividade é uma característica que deve ser valorizada no espaço rurbano, pois pode contribuir para a melhoria das condições de vida da população rural por meio do aumento da renda familiar (ZAFALON, 2015).

Segundo Graziano da Silva (2001), os processos de urbanização e de modernização agrícola integraram o espaço rural e urbano, urbanizando a população economicamente ativa (PEA) agrícola e aumentando a pluriatividade, bem como as ocupações rurais não agrícolas. Devido a essas transformações, a ideia de continuum rural-urbano caracteriza melhor esses ambientes do que uma oposição entre espaço e modo de vida do campo e da cidade. Desse modo, além do espaço rural e do espaço urbano, é possível tratar de um espaço rurbano, resultado da incorporação das características urbanas no meio rural.

D

D Devista da Associação Nacional de Pós-graduação e Pesquisa em Geografia (Anpege).

D D p.113-138, V.15, n.27, mai./ago. 2019. 
Assim, estaria ocorrendo um processo de rurbanização, sendo que a incorporação dessas características urbanas em certos espaços rurais seria tão forte que até mesmo impediria a nítida separação entre urbano e rural (GRAZIANO DA SILVA, 1999). Tal característica é evidente, na colônia Mergulhão.

Para Abramovay (2001), não se pode pensar o meio rural sem se pensar também o meio urbano, pois o dinamismo rural depende fundamentalmente da renda urbana, sobretudo daquela gerada pelo aproveitamento das virtudes mais valorizadas no meio rural, tais como a paisagem, a biodiversidade, a cultura e o modo de vida. Seguindo essa lógica, verifica-se que, na colônia Mergulhão, o apelo étnico/cultural foi uma estratégia adotada para se fomentar o turismo rural, ou seja, o resgate e a conservação da cultura italiana foram incorporados e se tornaram atrativos aos visitantes.

\section{Considerações finais}

A ideia da diferenciação do paranaense em relação aos habitantes das demais regiões do Brasil e a busca por características originais e definidoras desta população têm sido abordadas, desde o século XIX, alcançando o seu ápice, na década de 1920, com o paranismo. Desde então, a imigração de europeus não portugueses e a formação de uma população majoritariamente branca, no estado do Paraná - e, principalmente, em sua capital -, têm sido exaltadas por intelectuais e líderes políticos.

Tal discurso ganha força na capital paranaense, sobretudo a partir da década de 1990, com a administração municipal de Rafael Greca. A imagem de Curitiba como "a capital das nações" e de "cidade acolhedora de todos os povos" tem sido construída, nas últimas décadas, por meio de marketing político, de modo que esta identidade tem sido assumida pela população, de um modo geral.

No entanto, alguns grupos, tais como os índios e os negros, não foram enaltecidos por meio de representações identitárias. Enquanto que aos grupos brancos (europeus e asiáticos) são dedicadas praças, parques, monumentos, festas típicas e feiras gastronômicas, são quase inexistentes os símbolos que remetem às contribuições negra e indígena para a formação da população curitibana, num nítido processo de invisibilização dos grupos que fogem do padrão identitário idealizado.

Esse marketing étnico/cultural aparece em diversas políticas públicas da Região Metropolitana de Curitiba, com destaque para os circuitos de turismo rural, como, por exemplo, o Caminho do Vinho e o Caminho das Colônias, em São José dos Pinhais, e o Circuito Italiano, em Colombo. Assim, tratando-se especificamente dos italianos, a política 
de valorização deste grupo étnico é evidente na paisagem local, ganhando força, sobretudo, no bairro de Santa Felicidade, transformado em polo turístico gastronômico da cultura italiana em Curitiba.

Portanto, a origem europeia não portuguesa de grande parte da população curitibana é utilizada, na atualidade, para movimentar a economia local por meio do estímulo às atividades turísticas, mostrando que, de uma forma ou de outra, no passado e no presente, o processo de imigração iniciado no século XIX continua rendendo frutos políticos e econômicos ao estado do Paraná. O preço dessa política, no entanto, são a perpetuação de um mito e a construção idealizada de identidade - um discurso racista que contribui para manter desigualdades e preconceitos que, velados por belos discursos e por uma eficiente propaganda, parecem não existir em solo paranaense.

\section{Referências bibliográficas}

1. ABRAMOVAY, Ricardo. Ruralidade e desenvolvimento territorial. In: Gazeta Mercantil, 2001.

2. ALVIM, Zuleika M. F. Brava gente! Os italianos em São Paulo (1870-1920). São Paulo: Brasiliense, 1986.

3. BAlHanA, Altiva Pilatti. Política imigratória do Paraná. In: Revista Paraná Desenvolvimento, Curitiba, n. 87, jan/abr 1996, p. 39-50.

4. BITTELBRUN, Gabrielle Vivian. A negra que não está na capa de revista: debates sobre raça e gênero. In: Anuário de Literatura. Florianópolis, v. 21, n. 1, jun. 2016, p. 170-187.

5. CORONA, Hieda Maria Pagliosa. A agricultura familiar na RMC: um olhar sobre a relação ambiente e sociedade a partir da comunidade de Mergulhão. In: REDES, Santa Cruz do Sul, v. 16, n. 3, p. 138- 156, set/dez. 2011.

6. GRAZIANO DA SILVA, José. O novo rural brasileiro. Campinas: UNICAMP, 1999. Quem precisa de uma estratégia de desenvolvimento. In: NEAD. José Graziano, Jean Marc e Bianchini debatem "O Brasil rural precisa de uma estratégia de desenvolvimento". Brasília: MDA/CNDRS/NEAD, 2001.

8. GUTIÉRREZ, Horacio. Crioulos e africanos no Paraná, 1798-1830. In: Revista Brasileira de História. São Paulo, 8(16): 161-188, mar./ago. 1988.

9. MACHIOSKI, F. L. A preservação da identidade cultural em um grupo imigrante italiano Curato de Colombo, Paraná, 1888-1910. Monografia de conclusão de curso (Bacharelado em História). Curitiba: Universidade Federal do Paraná, 2004, 87p. 
10. . Colonos morigerados e laboriosos: o papel da imigração italiana no Paraná. In: Círculo de Estudos (PUCPR), v. 22, 2008.

11. MORAES, P. R. Bodê de.; SOUZA, M. Garcia de. Invisibilidade, preconceito e violência racial em Curitiba. In: Revista de Sociologia e Política, n. 13, p. 7-16, nov. 1999.

12. MOTA, L. T. As guerras dos índios Kaingang: a história épica dos índios Kaingang no Paraná (1769-1924). Maringá: Eduem, 2008. Disponível em: <

13. http://www.dhi.uem.br/laee/uploads/downloads/as-guerras-dos-indioskaingang--2009_1437774532.pdf >. Acesso: out. 2018.

14. OLIVEIRA, M. de. Imigração e diferença em um estado do Sul do Brasil: o caso do Paraná, 2007. In: Nuevo Mundo, Mundo Nuevos, 2007. Disponível em: <http:// nuevomundo.revues.org/5287>. Acesso em: maio 2017.

15. PRIORI, A. et al. História do Paraná: séculos XIX e XX [online]. Maringá: Eduem, 2012. A imigração, pp. 35-46.

16. REIS, Eligia Cristine; RODRIGUES, Isabel Cristina. Etnocentrismo: diversidades indígenas no Paraná. In: PARANÁ. Secretaria de Estado da Educação. Superintendência de Educação. Os desafios da escola pública paranaense na perspectiva do professor PDE 2016. Curitiba: SEED/PR, 2016, v. 1 (Cadernos PDE). Disponível em: <http://www. diaadiaeducacao.pr.gov.br/portals/cadernospde/pdebusca/producoes_pde/2016/2016_ artigo_hist_uem_eligiacristinereis.pdf>. Acesso em: 10/10/2018.

17. SALTURI, Luis Afonso. Paranismo, movimento artístico do Sul do Brasil no início do século XX. In: Perifèria, n. 11, dez. 2009.

18. SCHNEIDER, S. A importância da pluriatividade para as políticas públicas no Brasil. In: Revista de Política Agrícola, ano XVI, n. 3, Rio Grande do Sul, 2007.

19. STOLLMEIER, L. A.; OLIVEIRA, M. de. Indústria curitibana e imigração - o esboço de uma anatomia política do detalhe (1830-1930). In: Cadernos OBMigra, v. 1, n. 3, 2015.

20. VIACAVA, V. M. R. Em busca de Curitiba perdida: a construção do habitus curitibano. In: XII Simpósio Internacional Processo Civilizador: Civilização e Contemporaneidade, nov. 2009, Recife/PE. Anais do XII Simpósio Internacional Processo Civilizador: Civilização e Contemporaneidade. Recife, 2009.

21. WANDERLEY, Maria N. B. Raízes históricas do campesinato no Brasil. In: TEDESCO, João C. (org.). Agricultura familiar: realidades e perspectivas. Passo Fundo: EDIUPF, 1999, p. 23-56. 
22. ZAFALON, Rosana. O potencial do programa Vilas Rurais na promoção do desenvolvimento rural. In: Revista da Associação Nacional de Pós-Graduação e Pesquisa em Geografia (ANPEGE), p. 343-371, v. 11, n. 16, jul-dez. 2015.

D

D D Revista da Associação Nacional de Pós-graduação e Pesquisa em Geografia (Anpege).

$D^{D}$ p.113-138, V.15, n.27, mai./ago. 2019. 